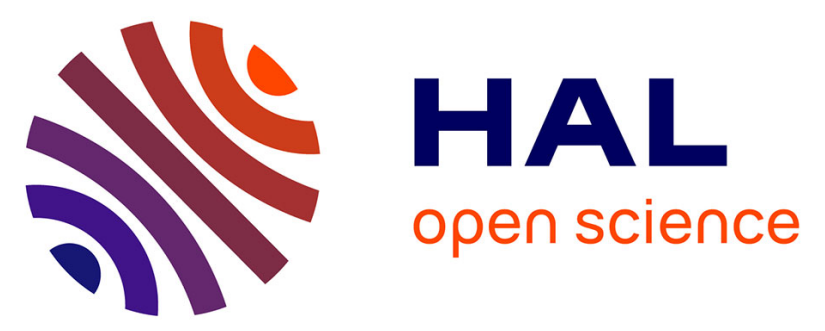

\title{
The effect of artificial feed on blood biochemistry profile and liver histology of wild saddled bream, (Sparidae)
} Josipa Ferri, Natalija Topić Popović, Rozelinda Čož-Rakovac, Blanka Beer-Ljubić, Ivančica Strunjak-Perović, Frane Škeljo, Margita Jadan, Mirela Petrić, Josip Barišić, Miljenko Šimpraga, et al.

\section{To cite this version:}

Josipa Ferri, Natalija Topić Popović, Rozelinda Čož-Rakovac, Blanka Beer-Ljubić, Ivančica StrunjakPerović, et al.. The effect of artificial feed on blood biochemistry profile and liver histology of wild saddled bream, (Sparidae). Marine Environmental Research, 2011, 71 (3), pp.218. 10.1016/j.marenvres.2011.01.006 . hal-00673199

\section{HAL Id: hal-00673199 \\ https://hal.science/hal-00673199}

Submitted on 23 Feb 2012

HAL is a multi-disciplinary open access archive for the deposit and dissemination of scientific research documents, whether they are published or not. The documents may come from teaching and research institutions in France or abroad, or from public or private research centers.
L'archive ouverte pluridisciplinaire HAL, est destinée au dépôt et à la diffusion de documents scientifiques de niveau recherche, publiés ou non, émanant des établissements d'enseignement et de recherche français ou étrangers, des laboratoires publics ou privés. 


\section{Accepted Manuscript}

Title: The effect of artificial feed on blood biochemistry profile and liver histology of wild saddled bream, Oblada melanura (Sparidae)

Authors: Josipa Ferri, Natalija Topić Popović, Rozelinda Čož-Rakovac, Blanka BeerLjubić, Ivančica Strunjak-Perović, Frane Škeljo, Margita Jadan, Mirela Petrić, Josip Barišić, Miljenko Šimpraga, Rino Stanić

PII:

$$
\text { S0141-1136(11)00017-1 }
$$

DOI:

$$
\text { 10.1016/j.marenvres.2011.01.006 }
$$

Reference: MERE 3502

To appear in: Marine Environmental Research

Received Date: 6 November 2010

Revised Date: 14 January 2011

Accepted Date: 24 January 2011

Please cite this article as: Ferri, J., Popović, N.T., Čož-Rakovac, R., Beer-Ljubić, B., Strunjak-Perović, I., Škeljo, F., Jadan, M., Petrić, M., Barišić, J., Šimpraga, M., Stanić, R. The effect of artificial feed on blood biochemistry profile and liver histology of wild saddled bream, Oblada melanura (Sparidae), Marine Environmental Research (2011), doi: 10.1016/j.marenvres.2011.01.006

This is a PDF file of an unedited manuscript that has been accepted for publication. As a service to our customers we are providing this early version of the manuscript. The manuscript will undergo copyediting, typesetting, and review of the resulting proof before it is published in its final form. Please note that during the production process errors may be discovered which could affect the content, and all legal disclaimers that apply to the journal pertain. 


\section{The effect of artificial feed on blood biochemistry profile and liver histology of wild saddled bream, Oblada melanura (Sparidae)}

Josipa Ferri ${ }^{\mathrm{a} *}{ }^{\text {, Natalija Topić Popović }}{ }^{\mathrm{b}}$, Rozelinda Čož-Rakovac ${ }^{\mathrm{b}}$, Blanka Beer-Ljubić ${ }^{\mathrm{c}}$, Ivančica Strunjak-Perović ${ }^{\mathrm{b}}$, Frane Škeljo ${ }^{\mathrm{a}}$, Margita Jadan ${ }^{\mathrm{b}}$, Mirela Petrić ${ }^{\mathrm{a}}$, Josip Barišić ${ }^{\mathrm{b}}$, Miljenko Šimpraga ${ }^{c}$, Rino Stanić ${ }^{d}$

${ }^{a}$ University of Split, Center of Marine Studies, Livanjska 5/III, 21000 Split, Croatia

${ }^{\mathrm{b}}$ Rudjer Boskovic Institute, Division of Materials Chemistry, Laboratory for Ichthyopathology - Biological Materials, Bijenicka 54, 10002 Zagreb, Croatia

${ }^{\mathrm{c}}$ University of Zagreb, Faculty of Veterinary Medicine, Department of Physiology and Radiobiology, Heinzelova 55, 10000 Zagreb, Croatia

${ }^{\mathrm{d}}$ Sardina d.o.o., 21410 Postira, Croatia

* corresponding author: e-mail: josipa.ferri@ unist.hr; tel: +38521558252; fax: +38521558257

\section{ABSTRACT}

Floating fish farms attract a great number of wild fish species, changing their behaviour and physiology. The saddled bream, Oblada melanura, sampled from populations aggregated around the Adriatic fish farm and from natural/control populations, were analysed for differences in eleven blood biochemistry parameters and liver histomorphology. The levels of lactate dehydrogenase (LDH), alkaline phosphatase (ALKP) and urea (URE) in cageassociated saddled bream $(428.00 \pm \mathrm{SD} 321.56 \mathrm{U} / \mathrm{L}, 86.13 \pm \mathrm{SD} 39.87 \mathrm{U} / \mathrm{L}$ and $0.05 \pm \mathrm{SD}$ $0.16 \mathrm{mmol} / \mathrm{L}$, respectively) were significantly lower than those observed in the control specimens $(1047.06 \pm \mathrm{SD} 505.56 \mathrm{U} / \mathrm{L}, 125.75 \pm \mathrm{SD} 34.70 \mathrm{U} / \mathrm{L}$ and $1.99 \pm \mathrm{SD} 0.73 \mathrm{mmol} / \mathrm{L}$, respectively). In contrast to that, concentrations of aspartate aminotransferase (AST) in cageassociated fish $(87.63 \pm$ SD $132.34 \mathrm{U} / \mathrm{L})$ were higher than values noted for the control population (6.55 \pm SD 5.90 U/L). URE and AST presented the main variables contributing to the discrimination between two analysed populations. One-way ANOSIM based on the blood parameters showed significant difference between saddled bream that fed around cages and those from the remote waters $(R=0.697 ; P<0.01)$. Hepatocytes of cage-associated fish contained large cytoplasmatic clear spaces indicating excessive accumulation of fat in the hepatocyte cytoplasm. All observed differences can be attributed to contrasting feeding behaviour of sampled populations but basic nutritional differences between them should be 
quantified in the future. Moreover, further research is necessary to detect their impact on the health status of the fish.

Keywords: Oblada melanura, Aquaculture, Food source, Blood chemistry, Liver histology, Effects-physiology, Adriatic

\section{Introduction}

Many fish species, from larvae to adults, are attracted to a high variety of natural and artificial objects (Dempster and Taquet, 2004). One of the most important artificial structures in Mediterranean pelagic systems are floating fish farms, whose strong aggregative effect on wild fish may be explained by increased food availability (Castro et al., 2002; Tuya et al., 2006). The phenomenon is widespread and dense aggregations around fish farms have been described across the Mediterranean Sea (Sanchez-Jerez et al., 2007; Fernandez-Jover et al., 2008). Although ecological impacts of fish farming on marine ecosystems have been widely documented (Naylor et al., 2000), impacts on behaviour and physiology of attracted wild fish species are scarcely reported. Attracted fish change diet, using uneaten food pellets as the main resource, which increases their biological condition but also affects the fatty acid composition (Sanchez-Jerez et al., 2007) and blood chemistry profile (Coz-Rakovac et al., 2008). Better understanding of the ecological effects of farming on wild fish populations is necessary, as the production from sea-cages continues to expand (FAO, 2008).

The saddled bream, Oblada melanura (Linnaeus, 1758), is common throughout the Mediterranean (including the Adriatic) and the eastern Atlantic, inhabiting littoral waters above rocky bottoms and Posidonia beds, down to $30 \mathrm{~m}$ deep (Bauchot and Hureau, 1986). Valle et al. (2007) and Fernandez-Jover et al. (2009) reported that $O$. melanura is one of the most abundant species found closely associated with the cages (south-eastern Spain), which are the settlement sites for juvenile saddled bream individuals. In the eastern Adriatic, aggregations of this opportunistic predator around cage installations are recently reported by fish farmers (personal observation), while wild populations of mullets, sea bass and sea bream are already documented as regular feeders in such areas (Coz-Rakovac et al., 2008; 2009).

Measurement of blood biochemistry parameters is commonly used diagnostic tool in biomonitoring and according to Coz-Rakovac et al. (2008) it presents good indicator of the artificial feed effects. In order to document and better understand variability and dynamics of 
blood chemistry parameters in general, few studies were conducted on the sea bass, Dicentrarchus labrax (Coz-Rakovac et al., 2005), sea bream, Sparus aurata (Coz-Rakovac et al., 2009), bluefin tuna, Thunnus thynnus (Topic Popovic et al., 2006; 2008), mullets (CozRakovac et al., 2008) and salmonids (Coz-Rakovac et al., 2002) in the eastern Adriatic. Although there is a lack of the basic data for the saddled bream, some baseline values of haematological parameters are available for other sparid species (Bollard et al., 1993; Carragher and Pankhurst, 1993; Coz-Rakovac et al., 2005; 2009). Therefore, there is a need for the basic blood chemistry values of $O$. melanura, as well as for the evaluation of the impact of floating fish farms on this species population.

The aim of this study was to investigate eleven blood biochemistry parameters (enzymes and metabolites) of the saddled bream captured in remote waters and nearby the fish farm in the central-eastern Adriatic. Moreover, measured blood parameters were correlated to different feeding patterns of the investigated species sampled from two localities, and could serve as biomarkers to infer the influence of floating fish farms to the local fish community. In order to assess the impact of different feeding regimes, the liver histomorphology of cage-associated and natural/control specimens was evaluated in detail. This paper presents the first data on the baseline blood chemistry values of $O$. melanura, species of a commercial interest in the Mediterranean and the Adriatic.

\section{Materials and methods}

\subsection{Fish sampling}

The saddled bream (O. melanura) specimens were collected during daylight hours using handline and purse seine. Fish samples were obtained from two localities in the centraleastern Adriatic located about $30 \mathrm{~km}$ apart, from the remote waters (between islands Orud and Stipanska) and nearby the sea bass (D. labrax) and sea bream (S. aurata) rearing cages (Maslinova Bay). The farm at Maslinova Bay was at a depth of 30 to $40 \mathrm{~m}$, with 22 cages of $12.5 \mathrm{~m}$ diameter and $8 \mathrm{~m}$ depth, 12 cages of $20 \mathrm{~m}$ diameter and $10 \mathrm{~m}$ depth and 5 cages of 30 $\mathrm{m}$ diameter and $10 \mathrm{~m}$ depth, producing almost $300 \mathrm{t} \mathrm{yr}^{-1}$. A total of 71 O. melanura were collected: 28 specimens caught in the immediate vicinity of the cages (cage-associated) using handline and 43 specimens caught in the remote waters (natural/control) using a purse seine. Cage-associated and control fishes were caught on two different random days but during the same period (June 2009) to avoid seasonal variation in further analyses. Sampled saddled 
bream did not manifest any external trauma, scars or injuries. Stress was minimized in duration, due to the small groups of fish that were selected for sampling at the time period, and rapid handling.

\subsection{Blood sampling and biochemical analyses}

Blood samples were collected from all sampled fish by caudal vein puncture, immediately after their capture. Samples were collected in tubes coated with anticoagulant lithium heparin, centrifuged at $12000 \mathrm{~g}$ for 90 seconds and the resultant plasma was frozen at $-20^{\circ} \mathrm{C}$ for storage until the analysis two weeks later. The biochemical analyses of parameters, such as aspartate aminotransferase (AST), gamma glutamyl transferase (GGT), creatine kinase (CK), lactate dehydrogenase (LDH), alkaline phosphatase (ALKP), glucose (GLU), urea (URE), creatinine (CRE), total proteins (TP), triglyceride (TRIG) and plasma cholesterol (CHOL), were carried out using a SABA-18 auto-biochemistry analyzer (AMS Analyzer Medical System, Rome, Italy).

\subsection{Liver collection and histological analyses}

Saddled bream were euthanized by severing the spinal cord, total length (TL, measured to the nearest $0.1 \mathrm{~cm}$ ) and weight $(\mathrm{W}$, measured to the nearest $0.1 \mathrm{~g}$ ) were recorded and sex was determined macroscopically by gonad observation. Total length of collected cage-associated and control saddled bream specimens ranged from 18.2 to $28.6 \mathrm{~cm}$ and from 24.0 to $30.5 \mathrm{~cm}$, respectively. Cage-associated fish ranged from 142.0 to $381.0 \mathrm{~g}$ weight while control fish ranged from 62.8 to $272.8 \mathrm{~g}$ weight. During necropsy, pieces of liver tissues were dissected and fixed in $10 \%$ buffered formalin for at least two weeks. After completion of fixation, tissue was removed from the fixative, dehydrated in a graded ethanol series (from $70 \%$ to $100 \%$ ), cleared in xylene and embedded in paraffin. Histological sections were cut at $5 \mu \mathrm{m}$, stained with haematoxylin-eosin and mounted permanently for microscopic analysis. All slides were examined 'blind' (to eliminate bias in interpretation) for abnormalities, such as lipid infiltration, degeneration and/or necrosis of hepatocytes. Pictures were loaded in

Olympus cell^A Imaging Software to measure area $\left(\mu \mathrm{m}^{2}\right)$ and perimeter $(\mu \mathrm{m})$ (average $\left.\pm \mathrm{SD}\right)$ of hepatocytes and nuclei.

\subsection{Statistical analyses}

Blood parameter values were tested for normality (Kolmogorov-Smirnov test of normality) and homogeneity of variance (Levene's test). Because these assumptions were not 
met by most of the plasma biochemical values, all data were $\log (\mathrm{x}+1)$ transformed before performing any statistical analysis. Relationships between fish length, weight and blood parameters of both sampled fish populations were tested using Spearman rank correlation. Two sample $t$-test was used to evaluate differences in condition index $\left(\mathrm{CI}=(100 \times \mathrm{W}) / \mathrm{TL}^{3}\right)$, blood parameters and area/perimeter of hepatocytes and nuclei between cage-associated and control fish population. A $P$ value $<0.05$ was considered to be significant, while a $P$ value $<$ 0.01 was considered to be highly significant.

In order to elucidate which combination of the plasma biochemical parameters best discriminates between two sampled saddled bream populations, eight parameters (meeting the assumptions of discriminant analysis) were subjected to the stepwise discriminant-function analysis $(F$ to enter $=1.0 ; F$ to remove $=0.0)($ statistical package STATISTICA, version 8.0. $)$. The basic principle of discriminant analysis is that groups of specimens can be divided according to functions that are linear combinations of the classifying variables (in this case, the biochemical parameters). We employed stepwise discriminant-function analysis approach, where at each step all variables are reviewed and evaluated to determine which one will contribute most to the discrimination between groups. That variable will then be included in the model, and the process starts again.

Plasma biochemical parameters of the saddled bream were $\log (\mathrm{x}+1)$ transformed and employed to construct a Bray-Curtis similarity matrix using the PRIMER 5 multivariate statistical package (v. 5.2.9; PRIMER-E Ltd). Resulting rank similarity matrix was subjected to non-metric multidimensional scaling (MDS) ordination, and subsequent one-way analysis of similarity (ANOSIM) to test whether the measured biochemical parameters differed significantly between cage-associated and control saddled bream populations.

\section{Results}

Necropsy of cage-associated fish revealed large amounts of visceral fat and yellowish liver while no macroscopic changes were found in control fishes. Moreover, during necropsy we observed the presence of commercial artificial feed in the digestive tract of most cageassociated specimens (21 out of 28), while guts of control fishes usually contained only small amounts of natural food. Significant differences existed in the condition index between studied fish groups. Cage-associated saddled bream had a higher CI (average 1.23 \pm SD 0.13) than the control fish (average $1.14 \pm$ SD $0.06 ; P=0.001$ ). 


\subsection{Blood chemistry}

Because no significant differences were found in blood parameter values between males and females of cage-associated and normal/control saddled bream, sexes were pooled within each population. Values of GLU and CHOL showed strong departure from normality even when $\log (\mathrm{x}+1)$ transformed so they were excluded from all statistical tests assuming normal data distribution. Moreover, GGT values were 0.00 in all but one case, so they were also excluded from further analyses.

As shown in Table 1, four plasma biochemical parameters varied significantly, with the exception of CK, CRE, TP and TRIG concentrations which displayed insignificant variation between cage-associated and control fishes. The levels of LDH, ALKP and URE in cage-associated saddled bream were significantly lower than those in control individuals. In contrast to that, the concentration of AST in cage-associated fish was higher than in the control population.

Spearman rank correlation of fish length, weight and plasma chemistry was conducted separately for control (Table 2) and cage-associated (Table 3) saddled bream. For control population, ALKP values significantly correlated $(P<0.05)$ with fish length, weight, CK, TP, TRIG and CHOL. AST increased with GLU, TP and CHOL, while CK increased with ALKP, CRE and TRIG $(P<0.05$ in all cases) (Table 2). For the cage-associated population, different pattern in correlation between parameters was observed (Table 3). The levels of ALKP increased with TP, TRIG and GLU while CK increased together with AST and GLU ( $P<$ 0.05 in all cases). Within the cage-associated population, significant negative correlation was estimated between GLU and LDH, CHOL and fish length, and URE and fish weight (Table $3)$.

Eight parameters were subjected to the stepwise discriminant function analysis, which included URE, AST, LDH and ALKP in the model, whereas CK, CRE, TP and TRIG were excluded $(F$ to enter $=1.0)$. The main variables contributing to the discrimination between cage-associated and control group were URE and AST (Table 4). Four included variables produced clear distinction between analysed groups, as indicated by a final Wilks' Lambda of 0.23 . The overall classification success of the discriminant analysis was $96 \%$, with correct affiliation of $93.33 \%$ in the cage-associated and $97.14 \%$ in the control group (Table 5). Although these values are very high, they were obtained by classifying cases from which the discriminant functions were computed, thus capitalizing on chance. A lesser accuracy can be expected when classifying new specimens based just on these four parameters. 
One-way ANOSIM (analysis of similarity) based on blood parameters showed high significant difference between cage-associated and natural/control population $(R=0.697 ; P<$ 0.01) (Fig. 1).

\subsection{Liver histomorphology}

Microscopic analysis of the liver sections demonstrated that control saddled bream specimens had no lipid accumulations, and hepatocytes were characterized with granular cytoplasm and central and round nucleus (Fig. 2A). The average area $\left(\mu \mathrm{m}^{2}\right)$ of hepatocytes and nuclei were 67.63 ( \pm SD 10.15) and 14.26 ( \pm SD 2.09), respectively (Table 6). The main alterations found in liver sections of cage-associated saddled bream were: irregular shaped nuclei, cytoplasmatic and nuclear degeneration, and melanomacrophages (Fig. 2B and Fig. 2C) which were identified as aggregates of cells containing dark-yellowish granules, normally close to the vessels. In general, hepatocytes of cage-associated fish contained large cytoplasmatic clear spaces which present excessive accumulation of fat in the hepatocyte cytoplasm (Fig. 2C). When comparing sizes of hepatocytes and nuclei between cageassociated and control saddled bream, all sizes were significantly larger in cage-associated saddled bream $(P<0.01$ in all cases $)$ (Table 6$)$.

\section{Discussion}

The saddled bream, $O$. melanura is a common member of the aggregated assemblage at the studied Adriatic fish farm (personal observation). However, small migrations of this species influence their abundances around cages throughout a year. Fish farmers observed the highest abundance of the saddled bream during summer and the lowest during winter months, when they are almost completely absent, and this corresponds to the data for this species around the fish farms in the western Mediterranean (Valle et al., 2007). The wild saddled bream feeds on a wide range of prey and could be considered as an opportunistic predator (Pallaoro et al., 2003). The results of the present observational study showed a change in the feeding behaviour of $O$. melanura around the cages because the majority of fish had pellets in their guts. Beside this qualitative observation of fish digestive tracts, future studies should quantify actual amounts of commercial feed in cage-associated fish. The changes in diet can in turn affect the condition index (Sanchez-Jerez et al., 2007), what is confirmed in this research. Cage-associated saddled bream had significantly higher condition index than control 
fish, most probably due to a diet based on the lost food pellets and a relative lack of exercise because of abundant, low-metabolic cost feeding opportunity. The same results were reported for the Mediterranean horse mackerel, Trachurus mediterraneus (Fernandez-Jover et al., 2007) and saithe, Pollachius virens (Skog et al., 2003). Furthermore, observed change of the feeding pattern of the saddled bream around cages influenced its blood indices when compared to active feeders of the natural population. A wide range of most blood chemistry values in both studied populations indicated high intraspecies variability. This characteristic feature of fish has been attributed to factors such as genetic variation, nutritional status, sex, age, and stress due to capture, handling and sampling procedures (Tavares-Dias et al., 2008). Moreover, because some blood chemistry variables are responsive to multiple endogenous and exogenous influences, the physiological significance of changes in blood chemistry can be uncertain (Wagner and Congleton, 2004) and caution must be taken when interpreting the results.

The lack of data of the aquaculture's impact on fish blood chemistry makes it difficult to evaluate our results. Some similarities can be noted with the work of Coz-Rakovac et al. (2008) who studied cage culture effect on blood chemistry profile of mullets. Results of both studies indicated that cage-associated fish exhibited a distinctly different response from the wild fish of the control population. In our study, URE and AST contributed the most to variations between two studied populations. According to Walsh et al. (2003), URE is present in all fish, and while the liver is the primary organ of its production, gills are the main organ of its excretion. The relatively low urea levels, as observed in cage-associated specimens, are usually the consequence of low protein diet (Topic Popovic et al., 2006), which we find unlikely according to the protein-rich diet of cage-associated fish. The enzyme AST is found in many fish tissues and therefore presents non-specific indicator of damage (Wagner and Congleton, 2004). According to Coz-Rakovac et al. (2008), the activity of this enzyme rises with fish starvation in natural/control population of mullets. However, this was not the case in our study because higher AST levels were observed in well fed specimens around cages. In addition, the fact that non-aggregated individuals are not eating a high-energy diet it does not mean that they starve. The increased AST activity in fish may reveal the possible leakage of this enzyme across damaged plasma membranes and/or the increased synthesis of the AST by the liver (Coz-Rakovac et al., 2005). The levels of AST showed positive correlation with the weight of specimens around cages indicating that an increase of transamination processes occurred with the increase of their respective body mass. The impact of the different living 
conditions and feeding regimes is evident, if we consider the significant differences of both parameters (URE and AST) between two studied populations.

Previous studies have shown that TP, CHOL and ALKP are responsive to changes in fish nutritional status. Storebakken et al. (1991) found that plasma concentrations of TP were positively correlated with feeding level in rainbow trout (Oncorhynchus mykiss), while other studies have shown declines in fish plasma TP during fasting (Navarro and Gutiérrez, 1995; Wagner and Congleton, 2004). On the contrary, Coz-Rakovac et al. (2008) found no correlation between TP values and the fish feeding regime. The observed lower TP values in well fed $O$. melanura around cages are similar to those estimated for the aquaculture-affected sea bream (Coz-Rakovac et al., 2009), but any conclusions that are not supported by significant results would be very speculative. Moreover, although a difference in plasma CHOL between sampled populations was observed, its significance could not be determined due to the strong departure from normality of even log-transformed values. According to Mensinger et al. (2005), CHOL levels can indicate disorders of lipid and lipoprotein metabolism and especially liver dysfunction. The polyfunctional enzyme ALKP is located primarily in the cell membrane, and has no known function in the blood, while plasma activities depend on the rate of leakage from cells and the rate of removal from the plasma (Wagner and Congleton, 2004). As well as TP plasma values, higher activity of ALKP was observed in specimens of control population, for which the metabolic activity of this enzyme increases as the fish grows (in both length and weight). Contrary to our results, high activity of ALKP is directly related to the increased feeding activity of fish, as suggested by Wagner and Congleton (2004). Positive correlation between these two parameters (ALKP and TP) was observed in both sampled populations and therefore pointed on their metabolic linkages.

Concentrations of GLU are also accepted as indicators of fish nutritional status. However, plasma GLU is highly responsive to stressors, so its variation in blood is likely to be more closely correlated with other stress indices than with nutritional status (Wagner and Congleton, 2004). A noticeable difference in plasma GLU levels between sampled fish populations was observed, but its significance could not be determined due to the strong departure from normality and equality of variance of even log-transformed GLU values. However, we can just point out that observed GLU values of both saddled bream populations were lower than those estimated for the aquaculture-affected sea bream (Coz-Rakovac et al., 2009). The levels of TRIG are considered to be major indices of the health status of teleost, but they are not a reliable indicator of fish nutritional status (Wagner and Congleton, 2004). On the contrary, Kavadias et al. (2004) demonstrated that high concentrations of plasma 
TRIG depend on the feeding rate while low levels can be explained by fish low-energy diet. However, no significant differences in the TRIG values between cage-associated and control saddled bream were observed in this study so conclusions can not be drawn.

Beside AST, CK and LDH are also useful indices of tissue damage because they may be released quite readily when only minor changes occur in the morphology and function of cells (Wagner and Congleton, 2004). The enzyme CK, which is concentrated in muscle and heart tissue, is an indicator of damage to one or both of these tissues and plays a key role in the energy homeostasis of cells. Elevated CK levels can be caused by many stressful events (Shahsavani et al., 2010) but no significant differences in this enzyme values between the two sampled populations were observed. According to Shahsavani et al. (2010), LDH catalyzes the conversion of lactate to pyruvate which is an important step in energy production of cells. High levels of LDH could be connected with hepatic necrosis, hepatic parenchyma lesions, fatty liver, skeletal muscle lesions, myocardial infraction, tumours (Topic Popovic et al., 2006) and many other possibilities. Interestingly, in our study, statistically higher LDH values were noted for control specimens, and not for cage-associated, which showed a fatty degeneration of liver hepatocytes. In general, the mean values of LDH of both populations were much higher than those reported for freshwater tilapia (Oreochromis niloticus) or juvenile red pacu (Piaractus brachypomus), which did not exceed 240 U/L (LeaMaster et al., 1990; Sakamoto et al., 2001). Luskova et al. (1995) observed significant correlation between LDH and CK levels in the nase, Chondrostoma nasus, but we have not found metabolic linkage of these parameters for the saddled bream.

Almost all CRE is excreted by the kidney so increased concentrations may reflect kidney dysfunction due to the structural damage (Burtis and Ashwood, 1996). However, we evaluated our results only according to different feeding behaviour, and the results showed positive correlation between CRE concentrations and the feeding level of the studied species. Detectable levels of GGT in plasma could not be established in previous studies (Manera and Britti, 2006; Topic Popovic et al., 2006), what is in agreement with our data if we exclude only one individual with detected value (maybe due to the sample artefact).

The MDS analysis showed that blood chemistry profile of $O$. melanura aggregated around fish farm was to some degree variable than that of the specimens caught in the wild. This could be the indicator of the recent arrival of new individuals at the farm. Moreover, different residence time at farms or short migrations of individual fish may explain differences in some parameters among the cage-associated fish. Unfortunately, we do not know the exact residence time of the sampled fish which could be helpful in results 
evaluation, but we can assume that $O$. melanura could have been resident for a maximum four months prior to our sampling in June (personal observation).

Comparative histological studies of liver of the saddled bream from two sampled populations provided an index to their general condition. Observed liver modifications in cage-associated specimens confirmed an evident effect of artificial feed and are reaction to imbalanced feeding or a nutritional pathological process (Tacon, 1996; Caballero et al., 2004). Anomalies such as irregular shaped hepatocytes and cytoplasmatic vacuolation were also described in populations of mullets (Coz-Rakovac et al., 2008) and sea bass (Coz-Rakovac et al., 2005) aggregated around fish farms. In general, this observed morphological pattern found in liver of cage-associated O. melanura is known as steatosis and was documented as a significant problem in cultured fish, specifically in sea bream (Benedito-Palos et al., 2008). The fatty degeneration of hepatocytes resulted in their significantly larger sizes when compared to hepatocytes of control specimens. Moreover, an increase in the density of the melanomacrophages, as observed for cage-associated fish in our study, is usually related to important hepatic lesions, such as degenerative and necrotic processes (Pacheco and Santos, 2002; Agius and Roberts, 2003).

In conclusion, O. melanura aggregated around fish farm in the eastern Adriatic underwent physiological changes. Qualitative observations during necropsy confirmed that their diet differed from control fish, and this affected their condition index, blood chemistry values and liver histomorphology. Reported data from this observational study are useful for evaluation of the health status of the wild saddled bream in both control and cage-associated conditions. However, further studies should include more fish farms and control locations, provide exact information of the residence time of the aggregated saddled bream around cages and the magnitude of their migrations in order to determine the scale of the influence of seacage fish farms.

\section{References}

Agius, C., Roberts, R.J., 2003. Melano-macrophage centres and their role in fish pathology. Journal of Fish Diseases 26, 499-509.

Bauchot, M.L., Hureau, J.C., 1986. Sparidae, in: Fishes of the North-eastern Atlantic and the Mediterranean. UNESCO, Paris, pp. 883-907. 
Benedito-Palos, L., Navarro, J.C., Sitjà-Bobadilla, A., Bell, J.G., Kaushik, S., Pérez-Sánchez, J., 2008. High levels of vegetable oils in plant protein-rich diets fed to gilthead sea bream (Sparus aurata L.): growth performance, muscle fatty acid profiles and histological alterations of target tissues. British Journal of Nutrition 100, 992-1003.

Bollard, B.A., Pankhurst, N.W., Wells, R.M.G., 1993. Effects of artificially elevated plasma cortisol levels on blood parameters in the teleost fish Pagrus auratus (Sparidae). Comparative Biochemistry and Physiology Part A: Molecular \& Integrative Physiology 106, 157-162.

Burtis, C.A., Ashwood, E.R., 1996. Tietz fundamentals of clinical chemistry, fourth ed. W.B. Saunders Company, Philadelphia.

Caballero, M.J., Izquierdo, M.S., Kjørsvik, E., Fernández, A.J., Rosenlund G., 2004. Histological alterations in the liver of sea bream, Sparus aurata L., caused by short- or long-term feeding with vegetable oils. Recovery of normal morphology after feeding fish oil as the sole lipid source. Journal of Fish Diseases 27, 531-541.

Castro, J.J., Santiago, J.A., Santana-Ortega, A.T., 2002. A general theory on fish aggregation to floating objects: An alternative to the meeting point hypothesis. Reviews in Fish Biology and Fisheries 11, 255-277.

Carragher, J.F., Pankhurst, N.W., 1993. Plasma levels of sex steroids during sexual maturation of snapper, Pagrus auratus (Sparidae), caught from the wild. Aquaculture 109, 375-388.

Coz-Rakovac, R., Teskeredzic, E., Strunjak-Perovic, I., 2002. Aminotransferase responses of coho salmon (Oncorhynchuss kisutch, Walbaum) to sea water challenge test in relation to temperature and salinity. Periodicum Biologorum 104, 211-215.

Coz-Rakovac, R., Strunjak-Perovic, I., Hacmanjek, M., Topic Popovic, N., Lipej, Z., Sostaric, B., 2005. Blood chemistry and histological properties of wild and cultured sea bass (Dicentrarchus labrax) in the north Adriatic Sea. Veterinary Research Communications 29, 677-687.

Coz-Rakovac, R., Strunjak-Perovic, I., Topic Popovic, N., Hacmanjek, M., Smuc, T., Jadan, M., Lipej, Z., Homen, Z., 2008. Cage culture effects on mullets (Mugilidae) liver histology and blood biochemistry profile. Journal of Fish Biology 72, 2557-2569.

Coz-Rakovac, R., Topic Popovic, N., Smuc, T., Strunjak-Perovic, I., Jadan, M., 2009. Classification accuracy of algorithms for blood chemistry data for three aquacultureaffected marine fish species. Fish Physiology and Biochemistry 35, 641-647. 
Dempster, T., Taquet, M., 2004. Fish aggregation device (FAD) research: gaps in current knowledge and future directions for ecological studies. Reviews in Fish Biology and Fisheries 14, 21-42.

FAO, 2008. The state of world fisheries and aquaculture 2008. Rapport, Food and Agriculture organization of the United Nations, Rome.

Fernandez-Jover, D., Jimenez, J.A., Sanchez-Jerez, P., Bayle-Sempere, J., Casalduero, F.G., Lopez, F.J., Dempster, T., 2007. Changes in body condition and fatty acid composition of wild Mediterranean horse mackerel (Trachurus mediterraneus, Steindachner, 1868) associated to sea cage fish farms. Marine Environmental Research 63, 1-18.

Fernandez-Jover, D., Sanchez-Jerez, P., Bayle-Sempere, J., Valle, C., Dempster, T., 2008. Seasonal patterns and diets of wild fish assemblages associated to Mediterranean coastal fish farms, ICES Journal of Marine Science 65, 1153-1160.

Fernandez-Jover, D., Sanchez-Jerez, P., Bayle-Sempere, J., Arechavala-Lopez, P., MartinezRubio, L., Jimenez, J.A., Lopez, F.J., 2009. Coastal fish farms are settlement sites for juvenile fish. Marine Environmental Research 68, 89-96.

Kavadias, S., Castritsi-Catharios, J., Dessypris, A., Miliou, H., 2004. Seasonal variation in steroid hormones and blood parameters in cage-farmed European sea bass (Dicentrarchus labrax L.). Journal of Applied Ichthyology 20, 58-63.

LeaMaster, B.R., Brock, J.A., Fujioka, R.S., Nakama, R.M., 1990. Haematologic and blood chemistry values for Sarotherodon melanotheron and a red hybrid tilapia in freshwater and seawater. Comparative Biochemistry and Physiology Part A: Molecular \& Integrative Physiology 97, 525-529.

Luskova, V., Lusk, S., Halacka, K., 1995. Yearly dynamics of enzyme activities and metabolite concentrations in blood plasma of Chondrostoma nasus. Folia Zoologica $44,75-82$.

Manera, M., Britti, D., 2006. Assessment of blood chemistry normal ranges in rainbow trout. Journal of Fish Biology 69, 1427-1434.

Mensinger, A.F., Walsh, P.J., Halon, R.T., 2005. Blood Biochemistry of the Oyster Toadfish. Journal of Aquatic Animal Health 17, 170-176.

Navarro, I., Gutiérrez, J., 1995. Fasting and starvation, in: Hochachka, P.W., Mommsen, T.P. (Eds.), Biochemistry and Molecular Biology of Fishes. Elsevier Science, New York, pp. 393-434. 
Naylor, R., Goldburg, R., Primavera, J., Kautsky, N., Beveridge, M., Clay, J., Folke, C., Lubchenco, J., Mooney, H., Troell, M., 2000. Effect of aquaculture on world fish supplies. Nature 405, 1017-1024.

Pacheco, M., Santos, M.A., 2002. Biotransformation, genotoxic and histopathological effects of environmental contaminants in European eel (Anguilla anguilla L.). Ecotoxicology and Environmental Safety 53, 331-347.

Pallaoro, A., Santic, M., Jardas, I., 2003. Feeding habits of the saddled bream, Oblada melanura (Sparidae), in the Adriatic Sea. Cybium 274, 261-268.

Sakamoto, K., Lewbart, G.A., Smith, T.M., 2001. Blood chemistry values of juvenile red pacu (Piaractus brachypomus). Veterinary Clinical Pathology 30, 50-52.

Sanchez-Jerez, P., Bayle-Sempre, J., Fernandez-Jover, D., Valle, C., Dempster, T., 2007. Ecological relationship between wild fish populations and Mediterranean aquaculture in floating fish cages. Impact of mariculture on coastal ecosystems, CIESM Workshop Monographs 32, 77-80.

Shahsavani, D., Mohri, M., Gholipour Kanani, H., 2010. Determination of normal values of some blood serum enzymes in Acipenser stellatus Pallas. Fish Physiology and Biochemistry 36, 39-43.

Skog, T.E., Hylland, K., Torstensen, B.E., Berntssen, M.H.G., 2003. Salmon farming affects the fatty acid composition and taste of wild saithe Pollachius virens L. Aquaculture Research 34, 999-1007.

Storebakken, T., Hung, S.S.O., Calvert, C.C., Plisetskaya, E.M., 1991. Nutrient partitioning in rainbow trout at different feeding rates. Aquaculture 96, 91-203.

Tacon, A.G.J., 1996. Lipid nutritional pathology in farmed fish. Archives of Animal Nutrition 49, 33-39.

Tavares-Dias, M., Affonso, E.G., Oliveira, S.R., Marcon, J.L., Egami, M.I., 2008. Comparative study on hematological parameters of farmed matrinxã, Brycon amazonicus Spix and Agassiz, 1829 (Characidae: Bryconinae) with others Bryconinae species. Acta Amazonica 38, 799-806.

Topic Popovic, N., Strunjak-Perovic, I., Coz-Rakovac, R., Hacmanjek, M., 2006. Plasma metabolites and enzymes of bluefin tuna, Thunnus thynnus and liver histology. Periodicum Biologorum 108, 127-131.

Topic Popovic, N., Srebocan, E., Coz-Rakovac, R., Hacmanjek, M., Strunjak-Perovic, I., Jadan, M., 2008. Blood biochemistry of captive Atlantic bluefin tuna Thunnus thynnus farmed in the Adriatic Sea. Journal of Applied Ichthyology 24, 614-616. 
Tuya, F., Sanchez-Jerez, P., Dempster, T., Boyra, A., and Haroun, R., 2006. Changes in demersal wild fish aggregations beneath a sea-cage fish farm after the cessation of farming. Journal of Fish Biology 69, 682-697.

Valle, C., Bayle-Sempere, J.T., Dempster, T., Sanchez-Jerez, P., Casalduero, F.G., 2007. Temporal variability of wild fish assemblages associated with a sea-cage fish farm in the south-wesetrn Mediterranean Sea. Estuarine and Coastal Shelf Science 72, 299307.

Wagner, T., Congleton, J.L., 2004. Blood chemistry correlates of nutritional condition, tissue damage, and stress in migrating juvenile chinook salmon (Oncorhynchus tshawytscha). Canadian Journal of Fisheries and Aquatic Sciences 61, 1066-1074.

Walsh, P.J., Mayer, G.D., Medina, M., Bernstein, M.L., Barimo, J.F., Mommsen, T.P., 2003. A second glutamine synthetase gene with expression in the gills of the Gulf toadfish (Opsanus beta). Journal of Experimental Biology 206, 1523-1533. 


\section{FIGURE LEGENDS}

Figure 1. MDS ordination showing relationship between cage-associated and control/natural O. melanura based on the set of biochemical parameters

Figure 2. Micrographs of the liver of O. melanura. A) normal hepatic tissue of control specimens; B) melanomacrophage aggregates (black arrows) close to a vessel and cytoplasmatic vacuolation (*) of cage-associated specimens; C) hepatocytes with empty vacuoles in cytoplasm (*) and irregular shaped nuclei with nuclear and cytoplasmatic degeneration (white arrows) of cage-associated specimens 


\section{TABLES}

Table 1. Comparative biochemical analysis of plasma parameters (AST - aspartate aminotransferase, GGT - gamma glutamyl transferase, CK - creatine kinase, LDH - lactate dehydrogenase, ALKP - alkaline phosphatase, GLU - glucose, URE - urea, CRE - creatinine, TP - total proteins, TRIG - triglyceride, CHOL - cholesterol) of natural/control and cageassociated $O$. melanura

\begin{tabular}{|c|c|c|c|c|c|}
\hline \multirow{2}{*}{ Parameters } & \multicolumn{2}{|c|}{ natural/control population } & \multicolumn{2}{|c|}{ cage-associated population } & \multirow{2}{*}{$P$} \\
\hline & Average \pm SD & Range & Average \pm SD & Range & \\
\hline AST (U/L) & $6.55 \pm 5.90$ & $0.17-21.30$ & $87.63 \pm 132.34$ & $1.21-443.40$ & $P<0.01$ \\
\hline GGT (U/L) & - & $0.00-0.00$ & $3.21 \pm 17.01$ & $0.00-90.00$ & - \\
\hline $\mathrm{CK}(\mathrm{U} / \mathrm{L})$ & $62.17 \pm 86.72$ & $4.00-400.00$ & $451.14 \pm 1367.51$ & $6.00-5186.00$ & $P>0.05$ \\
\hline $\mathrm{LDH}(\mathrm{U} / \mathrm{L})$ & $1047.06 \pm 505.56$ & $128.00-1762.00$ & $428.00 \pm 321.56$ & $96.00-1134.00$ & $P<0.01$ \\
\hline ALKP (U/L) & $125.75 \pm 34.70$ & $86.00-170.00$ & $86.13 \pm 39.87$ & $40.00-176.00$ & $P<0.05$ \\
\hline GLU (mmol/L) & $5.75 \pm 4.82$ & $0.02-15.48$ & $2.03 \pm 2.47$ & $0.11-6.71$ & - \\
\hline URE (mmol/L) & $1.99 \pm 0.73$ & $0.10-3.20$ & $0.05 \pm 0.16$ & $0.00-0.60$ & $P<0.01$ \\
\hline $\mathrm{CRE}(\mu \mathrm{mol} / \mathrm{L})$ & $41.08 \pm 8.57$ & $7.92-54.46$ & $39.22 \pm 13.86$ & $22.56-84.44$ & $P>0.05$ \\
\hline $\mathrm{TP}(\mathrm{g} / \mathrm{L})$ & $45.78 \pm 28.73$ & $26.00-118.00$ & $35.80 \pm 15.59$ & $16.00-56.00$ & $P>0.05$ \\
\hline TRIG (mmol/L) & $2.74 \pm 2.17$ & $0.09-8.72$ & $4.70 \pm 6.67$ & $0.04-19.59$ & $P>0.05$ \\
\hline $\mathrm{CHOL}(\mathrm{mmol} / \mathrm{L})$ & $4.31 \pm 3.74$ & $0.00-10.16$ & $7.62 \pm 3.82$ & $3.23-15.43$ & - \\
\hline
\end{tabular}

Table 2. Spearman rank correlation of fish length (TL), weight (W) and plasma chemistry variables (AST - aspartate aminotransferase, CK - creatine kinase, LDH - lactate dehydrogenase, ALKP - alkaline phosphatase, GLU - glucose, URE - urea, CRE - creatinine, TP - total proteins, TRIG - triglyceride) of natural/control O. melanura $(* P<0.05)$

\begin{tabular}{lccccccccccc}
\hline & TL & W & AST & CK & LDH & ALKP & GLU & URE & CRE & TP & TRIG \\
\hline W & $0.99^{*}$ & & & & & & & & & & \\
AST & 0.28 & 0.33 & & & & & & & & & \\
CK & -0.05 & -0.02 & -0.06 & & & & & & & & \\
LDH & -0.27 & -0.29 & 0.15 & 0.13 & & & & & & & \\
ALKP & $0.76^{*}$ & $0.74^{*}$ & 0.45 & $0.97^{*}$ & 0.29 & & & & & & \\
GLU & 0.04 & 0.06 & $0.61^{*}$ & -0.25 & -0.10 & -0.38 & & & & & \\
URE & -0.06 & -0.00 & -0.09 & 0.29 & -0.33 & 0.14 & 0.21 & & & & \\
CRE & 0.00 & 0.04 & 0.09 & $0.35^{*}$ & 0.03 & 0.25 & 0.22 & 0.17 & & & \\
TP & 0.27 & 0.35 & $0.78^{*}$ & 0.65 & 0.43 & $0.81^{*}$ & -0.34 & 0.00 & 0.15 & & \\
TRIG & 0.03 & 0.13 & 0.35 & $0.56^{*}$ & 0.26 & $0.85^{*}$ & 0.01 & 0.36 & -0.07 & 0.47 & \\
CHOL & 0.08 & 0.12 & $0.64^{*}$ & 0.06 & 0.06 & $0.87^{*}$ & $0.70^{*}$ & $0.60^{*}$ & 0.21 & 0.50 & $0.78^{*}$ \\
\hline
\end{tabular}


Table 3. Spearman rank correlation of fish length (TL), weight (W) and plasma chemistry variables (AST - aspartate aminotransferase, CK - creatine kinase, LDH - lactate dehydrogenase, ALKP - alkaline phosphatase, GLU - glucose, URE - urea, CRE - creatinine, TP - total proteins, TRIG - triglyceride) of cage-associated $O$. melanura $(* P<0.05)$

\begin{tabular}{lccccccccccc}
\hline & TL & W & AST & CK & LDH & ALKP & GLU & URE & CRE & TP & TRIG \\
\hline W & $0.87^{*}$ & & & & & & & & & & \\
AST & 0.51 & $0.71^{*}$ & & & & & & & & \\
CK & 0.15 & 0.18 & $0.85^{*}$ & & & & & & & \\
LDH & -0.38 & -0.25 & -0.32 & -0.28 & & & & & & \\
ALKP & -0.02 & 0.18 & 0.16 & 0.47 & -0.28 & & & & & \\
GLU & 0.08 & 0.15 & 0.10 & $0.55^{*}$ & $-0.61^{*}$ & $0.65^{*}$ & & & & & \\
URE & -0.42 & $-0.59^{*}$ & -0.06 & 0.17 & 0.04 & -0.41 & -0.28 & & & & \\
CRE & 0.04 & 0.16 & 0.12 & -0.02 & 0.06 & 0.10 & -0.05 & 0.10 & & & \\
TP & -0.17 & 0.04 & -0.25 & -0.03 & -0.14 & $0.68^{*}$ & 0.30 & -0.45 & -0.20 & & \\
TRIG & -0.09 & 0.16 & 0.02 & 0.41 & -0.25 & $0.53^{*}$ & $0.60^{*}$ & -0.35 & -0.33 & $0.75^{*}$ & \\
CHOL & $-0.69^{*}$ & -0.63 & -0.07 & 0.37 & -0.21 & 0.48 & 0.10 & - & -0.35 & 0.45 & $0.72^{*}$ \\
\hline
\end{tabular}

Table 4. Discriminant function analysis summary for the included plasma parameters (URE urea, AST - aspartate aminotransferase, LDH - lactate dehydrogenase, ALKP - alkaline phosphatase) of natural/control and cage-associated $O$. melanura

\begin{tabular}{lcccccc}
\hline Parameters & $\begin{array}{c}\text { Wilks' } \\
\text { Lambda }\end{array}$ & $\begin{array}{c}\text { Partial } \\
\text { Lambda }\end{array}$ & $\begin{array}{c}F \text {-remove } \\
(1.45)\end{array}$ & $P$-level & Tolerance & \multirow{2}{*}{$\mathrm{R}^{2}$} \\
\hline URE & 0.502005 & 0.444692 & 56.19358 & 0.000000 & 0.958767 & 0.041233 \\
AST & 0.294230 & 0.758720 & 14.31042 & 0.000455 & 0.877331 & 0.122669 \\
LDH & 0.242332 & 0.921207 & 3.84898 & 0.055979 & 0.992306 & 0.007694 \\
ALKP & 0.236512 & 0.943877 & 2.67571 & 0.108867 & 0.913318 & 0.086682 \\
\hline
\end{tabular}

Table 5. Classification matrix of the discriminant analysis between natural/control and cageassociated O. melanura, based on the blood parameters (URE - urea, AST - aspartate aminotransferase, LDH - lactate dehydrogenase and ALKP - alkaline phosphatase)

\begin{tabular}{lccc}
\hline \multirow{2}{*}{ Observed group } & \multicolumn{2}{c}{ Predicted group } & \\
\cline { 2 - 3 } & $\begin{array}{c}\text { natural/control } \\
\text { population }\end{array}$ & $\begin{array}{c}\text { cage-associated } \\
\text { population }\end{array}$ & Percentage Correct \\
\hline natural/control population & 34 & 1 & 97.14 \\
cage-associated population & 1 & 14 & 93.33 \\
Total & 35 & 15 & 96.00 \\
\hline
\end{tabular}


Table 6. Average and standard deviation of area $\left(\mu \mathrm{m}^{2}\right)$ and perimeter $(\mu \mathrm{m})$ of hepatocytes and nuclei of natural/control and cage-associated $O$. melanura

\begin{tabular}{llccc}
\hline \multirow{2}{*}{ nuclei } & & $\begin{array}{c}\text { natural/control } \\
\text { population }\end{array}$ & $\begin{array}{c}\text { cage-associated } \\
\text { population }\end{array}$ & \multirow{2}{*}{$P$} \\
\cline { 3 - 4 } & & Average \pm SD & Average \pm SD & \\
\hline \multirow{2}{*}{ Hepatocytes } & area $\left(\mu \mathrm{m}^{2}\right)$ & $67.63 \pm 10.15$ & $102.78 \pm 19.88$ & $P<0.01$ \\
& perimeter $(\mu \mathrm{m})$ & $33.39 \pm 2.57$ & $41.29 \pm 3.99$ & $P<0.01$ \\
& area $\left(\mu \mathrm{m}^{2}\right)$ & $14.26 \pm 2.09$ & $18.27 \pm 3.10$ & $P<0.01$ \\
& perimeter $(\mu \mathrm{m})$ & $15.72 \pm 1.21$ & $17.68 \pm 1.64$ & $P<0.01$ \\
\hline
\end{tabular}


Research highlights

- Oblada melanura around the cages used food pellets as the food resource

- change of the feeding pattern affected its blood indices (some values differed significantly between two studied populations) and liver histomorphology

- morphological pattern in liver, known as steatosis, occurred in cage-associated fish 


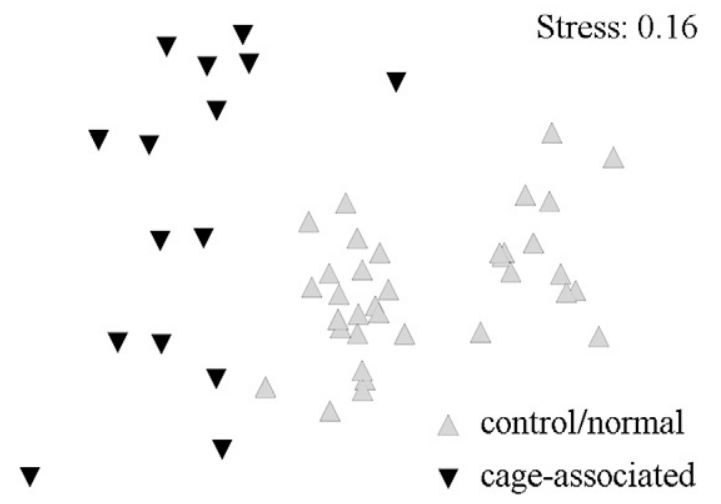




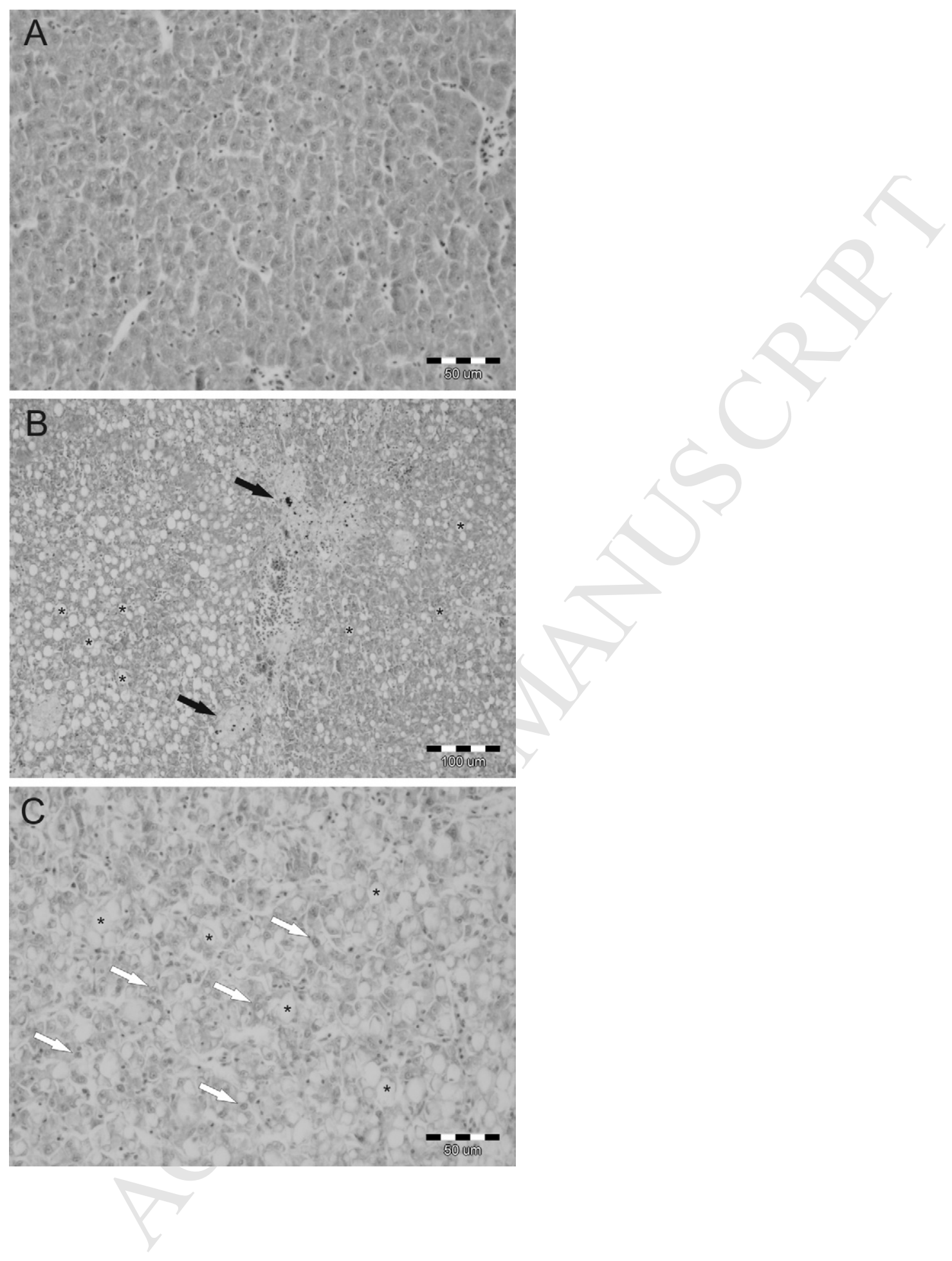

